\title{
TELEPRACA - NOWOCZESNA, ELASTYCZNA FORMA ZATRUDNIENIA I ORGANIZACJI PRACY - SZANSA CZY ZAGROŻENIE?
}

\begin{abstract}
W dobie globalizacji i społeczeństwa informacyjnego mamy do czynienia ze zmianą podejścia do zagadnienia pracy. Staje się ona coraz częściej usługą, która opiera się na zastosowaniu nowoczesnych technologii informacyjnych. Jedną $\mathrm{z}$ nietypowych form jej świadczenia jest telepraca. Pojęcie odnosi się do pracy prowadzonej w miejscu, które ogranicza czas dojazdu. Głównymi korzyściami dla pracodawcy są m.in.: dostęp do rozszerzonej podaży pracy, możliwość zatrudniania pracowników w niepełnym wymiarze czasu pracy, zwiększenie koniunktury i produktywności pracowników. Głównymi zaletami telepracy dla pracownika są natomiast: elastyczność wykonywanej pracy, zwiększenie produktywności, zmniejszenie kosztów i oszczędność czasu dla pracowników pełnosprawnych, szansa na pracę w domu. Pracowników biurowych można podzielić na różne kategorie. Typowymi telepracownikami są obecnie: pełnoetatowy pracownik biurowy; kobiety poszukujące dochodu, matki, które chcą wychowywać małe dzieci bez utraty w rozwoju ich kariery kierowniczej czy specjalistycznej oraz mężczyźni menedżerowie lub specjaliści, którzy cenią integrację pracy i życia rodzinnego. Dane potwierdzają występujący tzw. model telepracowników jako osób, które będą funkcjonować w niepełnym lub pełnym wymiarze czasu pracy w biurach, z przerwami na pewien krótszy lub dłuższy okres, w zależności od zmiany ich osobistej sytuacji życiowej. W artykule ukazano powstanie i ukształtowanie się definicji telepracy, klasyfikacje oraz wady i zalety w wymiarze indywidualnym i społecznym.
\end{abstract}

Słowa kluczowe: praca, telepraca, zatrudnienie.

\section{WPROWADZENIE}

W dobie globalizacji i społeczeństwa informacyjnego mamy do czynienia ze zmianą podejścia do zagadnienia pracy. Staje się ona coraz cześsiej usługą, która opiera się na zastosowaniu nowoczesnych technologii informacyjnych. Korzystanie z zaawansowanej technologii znajduje swoje odbicie w coraz większej popularności nietypowych form świadczenia pracy. Jedną z nich jest „telepraca”. Polega ona na wykorzystaniu nowoczesnych środków telekomunikacyjnych w celu realizacji różnych form pracy przez pracownika znajdującego się poza miejscem zatrudnienia. Obecnie coraz częściej podkreśla się, że pojęcie to dotyczy wykonywania pracy z dowolnej odległości od macierzystej firmy, do której należy dostarczyć efekty wykonywanych zadań, niemniej jednak nie ogranicza się wyłącznie do miejsca zamieszkania pracownika.

\section{POWSTANIE TELEPRACY I UKSZTAŁTOWANIE SIĘ JEJ DEFINICJI}

Telepraca jest formą pracy pozwalającą na jej uelastycznienie zarówno w czasie, jak i w przestrzeni. Podstawą organizacji telepracy jest korzystanie z nowoczesnych technik

\footnotetext{
${ }^{1}$ Dr hab. Beata Szluz, prof. UR, Zakład Socjologii Problemów Społecznych, Instytut Socjologii, Uniwersytet Rzeszowski; Aleja T. Rejtana 16 C, 35-959 Rzeszów, tel. (17) 872 13 30, e-mail: bszluz@univ.rzeszow.pl
} 
porozumiewania się z pracodawca, dzięki technologii teleinformatycznej poprzez sieci komputerowe, szybką transmisję danych i telefonię. W tym kontekście istotny jest zapis zawarty w Kodeksie pracy, który informuje o tym, że telepracę wykonuje się przy użyciu technologii informatycznych w ,rozumieniu przepisów o świadczeniu usług drogą elektroniczną"2. Ponadto zdefiniowano telepracę jako: „praca [...] wykonywana regularnie poza zakładem pracy, z wykorzystanie środków komunikacji elektronicznej w rozumieniu przepisów o świadczeniu usług drogą elektroniczną,33.

W raporcie R. Blanpaina, sporządzonym dla Komisji Europejskiej w 1995 r., telepraca określana jest jako praca wykonywana na rzecz pracodawcy lub klienta, głównie w miejscu innym niż tradycyjne miejsce pracy z wykorzystaniem technik informacyjnych ${ }^{4}$. Nowa forma zatrudnienia, jaką jest telepraca, to pojęcie trudne do jednoznacznego zdefiniowania. Sprawia wiele problemów interpretacyjnych osobom zajmującym się tym zagadnieniem.

Termin „telepraca” (telework) spopularyzowała Komisja Europejska ${ }^{5}$, z kolei w Stanach Zjednoczonych funkcjonuje określenie ,praca zdalna” (telecommuting), którego autorem jest Jack Nilles ${ }^{6}$. W 1973 r. przeprowadził on pierwszy eksperymentalny projekt telepracy. Twórca telepracy zauważył, że wszystko zaczęło się od prozaicznego pytania, które postawił pewien człowiek: ,jeśli ludzie potrafią stanąć na Księżycu, to dlaczego nie potrafią poradzić sobie z korkami ulicznymi?". Refleksja nad tym pytaniem doprowadziła do kolejnego: „czy wszyscy musimy chodzić do pracy, skoro istnieją możliwości techniczne, które pozwalają większości z nas na wykonanie wielu prac w domu lub jego pobliżu?"7. Dodatkowymi czynnikami stymulującymi teleworking były zatem zaistnienie pierwszego światowego kryzysu energetycznego i gwałtownego skoku cen paliwa oraz pojawienie się zagrożenia ekologicznego (w części spowodowanego emisją spalin samochodowych). W związku z tym rząd zaczął finansować pilotażowe programy z zakresu telecommuting i teleworking. Było to dobrym poczatkiem dla rozwoju teleworkingu w tym kraju.

Idea telepracy spopularyzował Alvina Tofflera w książce Trzecia fala (1980) oraz futurologa Francisa Kinsmana w książce The Telecommuters (1987). Jako pierwsza w Europie telepracę wprowadziła w latach sześćdziesiątych XX w. brytyjska firma programistyczna F. International, która zatrudniła kobiety w swoich domach. W 1973 r. uruchomiono pierwszy eksperymentalny projekt telepracy, mający na celu zbadanie ekonomicznych korzyści nowej formy zatrudnienia ${ }^{8}$. Następną ważną datą był rok 1980, kiedy to Toffler spopularyzował w książce Trzecia fala ideę „,elektronicznej wioski”, w której

\footnotetext{
${ }^{2}$ Ustawa z 24 sierpnia 2007 r. o zmianie ustawy - Kodeks pracy oraz niektórych innych ustaw (DzU z 2007, nr 181, poz. 1288, art. 67).

${ }^{3}$ Ibidem.

${ }^{4}$ Por. M. Janiec, T. Czerniak, W. Kreft, R. Piontek, Prowadzenie dziatalności biznesowej z zastosowaniem telepracy - poradnik, PARP, Warszawa 2006, s. 18

${ }^{5}$ Por. J. Jaczewski, Telepraca i jej idea, [w:] Telepraca - rynek pracy bez barier, red. C. Mrozińska, Krajowy Urząd Pracy, Warszawa 2001, s. 21-22.

${ }^{6}$ Por. J.M. Nilles, Telepraca, strategie kierowania wirtualnq zatogq, Wydawnictwo Naukowo-Techniczne, Warszawa 2003, s. 21.

${ }^{7}$ Ibidem, s. 7.

${ }^{8}$ Por. E. Bąk, Elastyczne formy zatrudnienia, C.H. Beck, Warszawa 2006, s. 54; J. Wiśniewski, Zatrudnienie pracowników w formie telepracy, TNOIK, Toruń 2007, s. 10.
} 
ludzie wykonują swoją pracę we własnych domach. W 1982 r. firma American Express podjęła program telepracy „Project Homebond” przeznaczony dla osób niepełnosprawnych ruchowo. W latach dziewięćdziesiątych rozwój telepracy zaczął przebiegać coraz szybciej. W 1992 r. firma AT\&T wprowadziła system telepracy, który w ciągu sześciu lat objął 55\% pracowników amerykańskich oddziałów firmy (36 tys. osób) ${ }^{9}$. W nieco innych okolicznościach doszło do wprowadzenia systemu telepracy w szwedzkim oddziale firmy Siemens-Nisdorf, kiedy to po raz kolejny został on zmuszony do zmiany swojej siedziby. W celu zapobiegnięcia utraty personelu, niezadowolonego ze zmiany lokalizacji pracy, postanowiono skorzystać z systemu teleworkingu. Po zawarciu odpowiedniej umowy, określającej czas pracy i zakres przyszłych obowiązków, każdy pracownik wyposażony został w komputer, modem, telefon komórkowy, dodatkową linię telefoniczną (w domu) oraz stał się integralną częścią specjalnego systemu komunikacyjnego, automatycznie lokalizującego pracowników ${ }^{10}$.

Telepraca jako forma zatrudnienia jest popularna w wielu krajach. W Stanach Zjednoczonych i w Europie na odległość pracuje po około 40 mln osób. Wśród krajów europejskich w zatrudnianiu telepracowników przodują kraje skandynawskie (w Szwecji i Finlandii zatrudnienie w tej formie stanowi około $15 \%$ wszystkich pracujących osób) oraz Holandia (14\%) i Belgia (11\%). Średni poziom zatrudnienia telepracowników w krajach Unii Europejskiej wynosi 11\%. W Polsce telepracownicy stanowią 1-2\% zatrudnionych ${ }^{11}$.

Sondaż HRK Partners i Szkoły Głównej Handlowej w Warszawie, na podstawie jednej z ogólnodostępnych baz danych przedsiębiorstw z 2003 r., objął firmy zatrudniające powyżej 100 pracowników i mające co najmniej dwa komputery. W wynikach wykazano, że telepracę stosuje 12,2\% przedsiębiorstw, gdzie telepracownicy stanowią najczęściej mniej niż 5\% ogółu zatrudnionych, natomiast $80,6 \%$ przedsiębiorstw nie stosowało telepracy jako formy organizacyjnej. Wśród osób, które pracują na odległość, wymieniano najczęściej: informatyków i projektantów systemów informatycznych, konsultantów (finansowych, marketingowych, technicznych, administracyjnych) oraz pracowników działów sprzedaży. Wśród osób, które nie korzystają z telepracy, 5,1\% deklarowało zainteresowanie jej wprowadzeniem w ciagu najbliższych dwóch lat. Odwrotny zamiar zdeklarowało $76,5 \%$ badanych. Jako uzasadnienie niewykorzystywania telepracy podawano: wykluczający ją przedmiot działalności firmy $(66,3 \%)$; wykluczający ją sposób organizacji firmy (30,6\%); niebezpieczeństwo niezachowania poufności powierzonych pracownikowi danych $(15,3 \%)$; utrudnienia w rozliczeniu rzeczywistego czasu pracy $(9,2 \%)$; nieumiejętność sprawdzenia należytego wywiązywania się z obowiązków telepracownika $(8,2 \%)^{12}$.

Z kolei na podstawie wyników przeprowadzonych w przedsiębiorstwach badań - podczas realizacji programu „Telepraca. Ogólnopolski program promocji i szkoleń dla przedsiębiorców” realizowanego od sierpnia 2005 do marca 2007 r., współfinansowanego ze

${ }^{9}$ Por. D. Nojszewski, Telepraca, „E-mentor. Dwumiesięcznik Szkoły Głównej Handlowej w Warszawie”, 2004/3, http://www.e-mentor.edu.pl/artykul/index/numer/5/id/61 (dostęp: 17.06.2013).

${ }^{10}$ Por. R. Deptuła, Teleworking jako alternatywna forma pracy w przyszłości, „Praca i Zabezpieczenie Społeczne" 1998/4, s. 13.

${ }^{11}$ Por. R. Szymczak, Internetowe miejsce pracy, Teczka informacyjna: Wojewódzki Urząd Pracy w Warszawie, Centrum Informacji i Planowania Kariery Zawodowej, Warszawa 2006, http://www.wup.mazowsze.pl/ciz/teczki/telepraca.pdf (dostęp: 10.05.2010).

${ }^{12}$ Por. M. Pawłowska, Perspektywy rozwoju telepracy w Polsce - raport z badań, „E-mentor. Dwumiesięcznik Szkoły Głównej Handlowej w Warszawie" 2009/3, http://www.e-mentor.edu.pl/artykul/index/numer/30/id/662 (dostęp: 10.12.2010) 
środków Unii Europejskiej - stwierdzono, że jest ona najczęściej wykorzystywana w małych firmach, liczących do 9 pracowników (13\% przedsiębiorstw). Branże, w których jest stosowana to: działalność wydawnicza, poligrafia i reprodukcja zapisanych nośników informacji (22\% przedsiębiorstw); produkcja sprzętu i aparatury radiowej, telewizyjnej, komunikacyjnej (20\%); pośrednictwo finansowe (19\%); produkcja maszyn biurowych i komputerów (16\%) oraz prowadzenie prac badawczo-rozwojowych (16\%). Perspektywy wdrożenia telepracy są obiecujące. Spośród wszystkich badanych firm 19\% rozważa jej wprowadzenie w najbliższej przyszłości ${ }^{13}$.

\section{KLASYFIKACJA RODZAJÓW TELEPRACY}

Spotyka się wiele form telepracy, w zależności od tego, jakie kryteria weźmie się pod uwagę. Wyróżniono kilka głównych rodzajów telepracy:

1) telepraca wykonywana $\mathrm{w}$ domu - pracownik pracuje w domu i porozumiewa się ze swoim pracodawcą jedynie za pomocą odpowiednich środków łączności;

2) telepraca wykonywana poza domem pracownika, w ściśle określonym miejscu w postaci: telecentrum, telechatki, telewioski;

3) telepraca nomadyczna (mobilna). wyróżnić:

Ze względu na miejsce wykonywania telepracy i czas na nią poświęcony można

1) telepracę sporadyczną (ad hoc teleworking) - praca wykonywana jest biurze, ale w sporadycznych przypadkach lub w ściśle określonym czasie wykonywana jest w domu lub poza siedzibą pracodawcy;

2) telepracę domową zmienną (alternatig home-based teleworking) - praca wykonywana jest w większości poza biurem pracodawcy, ale w określonym czasie wykonuje się ją w biurze;

3) telepraca domowa (home-based teleworking) - praca wykonywana $\mathrm{w}$ domu, bez dojeżdżania do siedziby pracodawcy;

4) telepraca mobilno-nomadyczna (nomadic teleworking) - praca, która ze względu na swój charakter wykonywana jest poza siedzibą pracodawcy, a pracownicy posługują się telefonem komórkowym, pagerem czy też komunikują się za pomocą Internetu $^{14}$.

Najbardziej popularną formą telepracy jest praca wykonywana wyłącznie w domu pracownika, korzystającego z technologii informatycznych. Praca w domu może mieć postać tzw. domowego biura (home office). Jest to wydzielona część domu pracownika, gdzie stanowisko dostosowane jest do standardowego wyposażenia biura. W ramach telepracy domowej można wyróżnić kilka form organizacyjnych:

1) telepracę wykonywaną na rzecz jednego pracodawcy;

2) telepracę wykonywaną dla jednego lub kilku pracodawców (ten rodzaj telepracy jest charakterystyczny dla przedstawicieli wolnych zawodów);

3) telepracę wykonywaną częściowo w domu, a częściowo w firmie ${ }^{15}$.

Ostatni wymieniony typ zwany jest telepracą przemienną. Łączy się z pojęciem telepracy ruchomej, która umożliwia połączenie pracy w biurze $\mathrm{z}$ pracą poza biurem oraz

\footnotetext{
${ }^{13}$ Ibidem.

${ }^{14}$ Por. E. Bąk, op. cit., s. 56.

${ }^{15}$ Por. D. Książek, Telepraca, ,Praca i Zabezpieczenie Społeczne” 2004/7, s. 9.
} 
telepracy na wezwanie, polegającej z kolei na zdalnym doglądaniu oraz naprawie urządzeń i sieci w czasie dyżuru pracownika w jego domu.

Telepracownikami świadczącymi telepracę domową mogą być osoby: zatrudnione na etacie, samozatrudniające się lub kontaktowi telepracownicy nieformalni, a także telepracownicy-przedsiębiorcy ${ }^{16}$.

Innym rodzajem telepracy indywidualnej jest praca mobilna. Pracownik nie jest związany z siedzibą firmy ani z domem, ale wykonuje swoje obowiązki w podróży służbowej. Telepracownik nomadyczny pracuje tam, gdzie akurat przebywa, np. w hotelu, pociagu, samolocie. Ograniczeniem jest tylko dostęp do odpowiednich łączy telekomunikacyjnych, które umożliwiają transfer danych.

Kolejnym rodzajem jest praca w telecentrach. Telecentrum jest to biuro zorganizowane poza siedzibą firmy, które jest wyposażone w infrastrukturę teleinformatyczną. Zwykle telecentra są zakładane w pobliżu miejsca zamieszkania pracowników, co pozwala na wyeliminowanie dojazdów do siedziby pracodawcy, a także umożliwia pracownikowi przyjazd do telecentrum, którego lokalizacja najbardziej mu odpowiada.

Telecentra mogą być własnością jednej firmy, istnieje także możliwość posiadania przez jedną firmę stanowisk roboczych w centrum należącym do kilku instytucji. Jak pisze Janusz Wiśniewski: ,zadaniem telecentrów jest stworzenie odpowiedniego stanowiska pracy dla potencjalnych pracowników danego pracodawcy, nakierowane na realizację konkretnych zadań przez niego wyznaczonych"17. Czynnikiem wyróżniającym telecentrum jest brak przypisania danego pracownika do konkretnego stanowiska pracy zwany „gorącym biurkiem" ${ }^{\text {. }}$. Do pracy w telecentrum wykorzystuje się Internet, Intranet i Extranet. W telecentrach mogą pracować osoby, które nie mogą lub nie chcą wykonywać swojej pracy w domu, a dojazd do głównej siedziby firmy jest dla nich zbyt kosztowny lub czasochłonny.

W literaturze przedmiotu wyróżniono szczególny rodzaj telecentrum, które jest określane jako lokalne ${ }^{19}$. W odróżnieniu od telecentrum będącego własnością wykorzystującej go firmy, jest ono odrębną jednostką gospodarczą. Zwykle jest tworzone przez niezależne instytucje prywatne lub publiczne udostępniające swoje zasoby firmom lub osobom, które chcą pracować w formie telepracy. Zasoby telecentrum lokalnego udostępniane są odpłatnie lub nieodpłatnie. Telecentra lokalne obsługują zazwyczaj najbliższe otoczenie. Często nazywane są sąsiedzkimi centrami telepracy. Głównym czynnikiem sprzyjającym powstaniu centrum sąsiedzkiego jest wyeliminowanie dojazdów samochodem do pracy, a także ograniczenie korzystania z komunikacji miejskiej. Pełni ono funkcję komercyjną, gdyż umożliwia określonej liczbie osób wykonanie ściśle pracowniczych obowiązków.

Innym rodzajem telecentrum jest ,telechatka”. Nazwa pochodzi od lokalizacji na terenie wiejskim. Telechatki organizuje się najczęściej w adaptowanych wiejskich domach, nieużywanych pomieszczeniach gospodarczych lub szkołach. Jej zastosowanie wskazuje Ewa Bąk, pisząc: ,pierwotnym przeznaczeniem telechatki było zapewnienie dostępu do najnowszych technologii dla ludzi oddalonych od centrów urbanistycznych, wyposażonych w sprzęt najnowszej generacji ${ }^{\prime 20}$. Ze względu na ograniczony dostęp do nowocze-

\footnotetext{
${ }^{16}$ Więcej na ten temat zob. M. Janiec, T. Czerniak, W. Kreft, R. Piontek, op. cit., s. 27-28.

${ }^{17}$ J. Wiśniewski, op. cit., s. 53.

${ }^{18}$ M. Janiec, T. Czerniak, W. Kreft, R. Piontek, op. cit., s. 29.

${ }^{19}$ Ibidem, s. 30.

${ }^{20}$ E. Bąk, op. cit., s. 57.
} 
snych technologii mieszkańcy społeczności wiejskich i małomiasteczkowych nie zawsze mogli liczyć na zatrudnienie w przedsiębiorstwach opierających swoją działalność na nowoczesnej technice i temu właśnie telechatki miały przeciwdziałać. Odgrywają one potrójną rolę: rynkową, społeczno-wychowawczą i edukacyjną ${ }^{21}$. Szczególny nacisk kładzie się na rolę edukacyjną, ponieważ telechatki zapoznają lokalne przedsiębiorstwa i osoby indywidualne $\mathrm{z}$ możliwościami najnowszych rozwiązań teleinformatycznych. Z tym wiąże się także funkcja społeczna, pozwalająca na walkę z wykluczeniem cyfrowym (digital divide). Telechatki umożliwiają ponadto miejscowym telepracownikom nawiązanie wzajemnych kontaktów, pozwalając na organizację społeczności lokalnej na rynku pracy. W Polsce telechatki mają m.in. takie firmy jak: Call Center Poland, Work Service, Polkomtel. Wśród firm zagranicznych przykładami mogą być np. Lufthansa, IBM, American Express, British Gas, British Telecom.

Rozwinięciem idei telechatki są ,telewioski”. Tworzą je połączone w ramach określonego obszaru telechatki, które z kolei stanowią zintegrowaną sieć wioskową. Jest ona przyłączana do krajowej sieci szkieletowej. Telepraca w telewiosce umożliwia aktywność osobom, które preferują wiejski styl życia, ale w połączeniu z profesjonalnym dostępem do sieci teleinformatycznej.

Funkcjonującym współcześnie rodzajem pracy jest telepraca określana jako tzw. zamorska, która wiąże się z wyprowadzeniem pracy poza teren własnego regionu, miasta czy nawet kraju. Dzięki zastosowaniu technologii ICT miejsca pracy mogą być szybko przenoszone do różnych miast, regionów i krajów. Taki termin stworzono w latach 19921993 na potrzeby raportu Studium na temat telepracy, telehandlu i otwartych sieci elektronicznych (Study of Telework, Teletrade and Open Electronic Networking), przygotowanego dla Departamentu Handlu i Przemysłu Rządu Brytyjskiego ${ }^{22}$.

W literaturze wymieniany jest także outsourcing, który polega na zlecaniu wykonania pewnych prac firmom zewnętrznym. Wykorzystywany jest on, gdy skala przedsięwzięcia jest duża i długofalowa. Firma przyjmująca zlecenie może znajdować się w tym samym mieście czy regionie co firma zlecająca, ale może także mieścić się w innym kraju. Dzięki nowoczesnej technice informatycznej pozwala na połączenie popytu z podażą pracy bez migracji siły roboczej. Jednak w wypadku małej skali przedsięwzięcia nie może być mowy o outsourcingu, a jedynie o wynajęciu telepracowników.

Ostatnim rodzajem telepracy jest „suport”, który polega na świadczeniu usług standardowych, głównie za pomocą telefonu i Internetu. Jest zbliżony do telemarketingu. Należy jednak podkreślić, że ostatni rodzaj, a zwłaszcza telepraca zamorska, nie oznacza prostego przesunięcia pracy do krajów, gdzie koszty są niższe (tzw. „zjawisko dumpingu społecznego" - wyprowadzania miejsc pracy poza kraj, do miejsc z tańszą siłą robocza). Na przykład wytwarzanie oprogramowania staje się specjalizacją Indii, administracja systemami i zarządzanie danymi - Filipin, zajmowanie się systemami obsługi klientów są domeną Indii, w Polsce otwierane są centra obsługi księgowej poszczególnych firm ${ }^{23}$. Telepraca jest rozwijana efektywnie w regionach, gdzie istnieje odpowiednia kombinacja kosztów, umiejętności oraz indywidualnej przedsiębiorczości.

\footnotetext{
${ }^{21}$ D. Książek, op. cit., s. 9.

${ }^{22}$ Por. K. Romańska, Elastyczna forma zatrudnienia - telepraca, [bw.], Warszawa-Łódź 2009, s. 21.

${ }^{23}$ Ibidem.
} 


\section{TELEPRACA W WYMIARZE INDYWIDUALNYM I SPOLECZNYM - ZA- LETY I WADY}

Powołując się Gila Gordona można zauważyć, że telepraca ma dwie strony: dobrą i złą. Dobra strona to ta, że można pracować w każdym miejscu i o każdej porze. Zła natomiast to ta, że można pracować w każdym miejscu i o każdej porze ${ }^{24}$.

Jak twierdzi Jack Nilles telepraca jest rodzajem pracy, w której korzyści przeważają nad zagrożeniami ${ }^{25}$. Jednak ze względu na liczne uwarunkowania telepracy warto przyjrzeć się jej wadom i zaletom, zarówno w wymiarze indywidualnym, jak i społecznym. W wymiarze indywidualnym wady i zalety telepracy mogą występować zarówno po stronie telepracownika, jak i pracodawcy. W szerszym wymiarze - społecznym - wady i zalety tego rozwiązania mają znaczenie dla grup społecznych, środowiska naturalnego oraz dla sytuacji ekonomicznej i gospodarczej.

Z punktu widzenia pracodawcy telepraca niesie ze sobą wiele korzyści w wymiarze indywidualnym. Należą do nich:

1) zmniejszenie kosztów pracy poprzez ich eliminację w kontekście wynajęcia, urządzenia i utrzymania biura;

2) zmniejszenie kosztów związanych $\mathrm{z}$ nadgodzinami, zwolnieniami lekarskimi i spóźnieniami;

3) możliwość zatrudnienia pracowników z rejonów, gdzie koszty pracy są niższe oraz osób z różnych względów wykluczonych z rynku pracy;

4) pozyskanie wysoko wykwalifikowanych specjalistów, których nie ma na lokalnym rynku pracy, ale bez konieczności przenoszenia ich do miejscowości, w której mieści się siedziba firmy;

5) ograniczenie wpływu zmiany siedziby firmy na fluktuację jej pracowników;

6) zwiększenie konkurencyjności firmy poprzez m.in. elastyczność rozproszonych zespołów, większy dostęp do klienta oraz operatywność telepracowników, którzy pozostają do dyspozycji klientów przez 24 godziny na dobę. Dzięki telepracy zwiększa się także możliwość dotarcia z danym produktem do większej grupy potencjalnych odbiorców, do których tradycyjny dostęp jest niemożliwy lub utrudniony. Telepraca pozwala więc na zwiększenie sprzedaży i rozwój firmy ${ }^{26}$.

W latach 1999-2001 Centrum Promocji Kobiet wraz ze Stowarzyszeniem SEFIA z Paryża oraz Litewskim Stowarzyszeniem Kobiet z Wilna zrealizowało projekt badawczo-szkoleniowy Telepraca szansq dla kobiet, dotyczacy telepracy jako nowej formy zatrudnienia. Celem tego projektu było zbadanie możliwości pracy na odległość w warunkach polskiej/litewskiej rzeczywistości społecznej i prawnej oraz zapoznanie się partnerów z Polski i Litwy z rozwojem rynku telepracy we Francji. Rezultatami projektu są: przygotowanie materiałów na temat telepracy, przeprowadzenie badań wśród firm oraz przygotowanie podręcznika dla trenerów. Kolejnym projektem, w którym udział wzięło Centrum Promocji Kobiet, był europejski projekt Eastern Europe E-work, przeznaczony dla kadry kierowniczej przedsiębiorstw związanych z rozwojem nowych technologii. Jego celem było promowanie telepracy w krajach kandydujących do Unii Europejskiej oraz

\footnotetext{
${ }^{24}$ Por. M. Piasecki, Telepraca osób niepetnosprawnych w spoteczeństwie informacyjnym, „Telekomunikacja i Techniki Informacyjne" 2001/2, s. 61.

${ }^{25}$ Por. J. Nilles, op. cit, s. 22.

${ }^{26}$ Por. E. Bąk, op. cit., s. 63.
} 
przekazanie im doświadczeń i umiejętności społeczeństwa informacyjnego krajów członkowskich. Projekt ten był realizowany w ramach współpracy pięciu krajów Europy Wschodniej: Polski, Litwy, Łotwy, Węgier i Rumunii ${ }^{27}$. Badania Centrum Promocji Kobiet przeprowadzone w $2000 \mathrm{r}$. wskazują na trzy istotne zalety telepracy dla pracodawcy:

1) zmniejszenie kosztów urządzenia i utrzymania biura;

2) wzrost elastyczności rodzaju wykonywanych prac i ich terminów;

3) wzrost produkcji ${ }^{28}$.

Z kolei z punktu widzenia pracownika telepraca ma istotne zalety. Należą do nich:

1) możliwość zatrudnienia dla osób, które z różnych względów nie mogą opuścić mieszkania;

2) łatwiejszy dostęp do pracy, bez konieczności przeprowadzki;

3) elastyczność wyboru miejsca zamieszkania, co wiąże się z kosztami utrzymania;

4) niezależność utrzymania stanowiska pracy od zmiany lokalizacji firmy;

5) dostosowanie rytmu i czasu pracy do własnych możliwości;

6) ograniczenie czasu poświęconego na dojazdy do pracy oraz kosztów z tym związanych;

7) praca w przyjaznych warunkach;

8) brak stresu związanego z pracą;

9) brak konfliktów pracowniczych;

10) wyższe zarobki telepracowników;

11) konieczność oraz możliwość stałego podnoszenia kwalifikacji zawodowych związana $\mathrm{z}$ rozwojem technologii teleinformatycznych;

12) godzenie pracy i życia rodzinnego;

13) równowaga między karierą zawodową a życiem prywatnym;

14) wyższa wydajność ${ }^{29}$.

Istotną zaletą telepracy jest także to, że pracownik w tym samym czasie może wykonywać zadania dla wielu pracodawców.

Jednakże wymienione zalety telepracy nie równoważą jej wad. Ze strony pracodawcy do wad tych należą:

1) brak lub ograniczenie kontroli nad telepracownikiem i zmniejszenie poczucia identyfikacji pracownika $\mathrm{z}$ firmą;

2) ryzyko związane $z$ bezpieczeństwem danych;

3) możliwość utraty klientów, którzy preferują tradycyjne formy kontaktu z pracownikami firmy;

4) możliwość awarii sprzętu teleinformatycznego ${ }^{30}$.

Brak identyfikacji telepracownika z firmą może mieć poważne konsekwencje dla pracodawcy. Pracownika słabo identyfikującego się z firmą trudno zatrzymać, gdyż telepraca może spowodować jego usamodzielnienie się i chęć niezależności ${ }^{31}$. Negatywne skutki

\footnotetext{
${ }^{27}$ Por. M. Pawłowska, op. cit.

${ }^{28}$ Por. E. Konarska, K. Polańska, Telepraca jako nowa forma organizacji pracy i zatrudnienia, [w:] Telepraca szansa czy zagrożenie na rynku pracy, 2002, http//www.univ.szczecin.pl/zsgi/konferencja/5/ (dostęp: 15.05.2006)

${ }^{29}$ Por. E. Bąk, op. cit., s. 64; M. Janiec, T. Czerniak, W. Kreft, R. Piontek, op. cit., s. 60-61.

${ }^{30}$ E. Bąk, op. cit., s. 65 .

${ }^{31}$ Por. E. Krok, Telepraca - aspekty ekonomiczna i społeczna, [w:] Telepraca - szansa czy zagrożenie na rynku pracy..., (dostęp: 15.05.2006)
} 
tego działania mogą być widoczne zwłaszcza w trakcie realizacji ważnych projektów, gdy telepracownik zrezygnuje z pracy lub też z powodu obowiązków u innych pracodawców będzie opóźniał wykonanie swoich zadań.

Wady telepracy stają się widocznymi barierami we wdrażaniu tej formy organizacji pracy. Dochodzą do tego ponadto:

1) wysokie koszty początkowe - zapewnienie technologicznego wsparcia dla telepracy oraz oprzyrządowanie i zagwarantowanie bezpieczeństwa danych stanowią poważną wadę;

2) sprzeciw kadry kierowniczej - barierą wobec telepracy nie jest niejednokrotnie technologia, lecz sprzeciw menedżerów wobec zmian;

3) konieczność przedefiniowania wewnętrznych reguł przedsiębiorstwa - zwykle dotyczy to działu zarządzania zasobami ludzkimi, a w mniejszych firmach kadr, gdzie należy dokonać zmian treści umów i zasad kontroli w zależności od rodzaju i zakresu telepracy;

4) trudności w zarządzaniu zasobami ludzkimi firmy - chodzi o zarządzanie efektami pracy, monitorowanie postępu oraz motywowanie pracowników, których rzadko widzi się w siedzibie firmy;

5) brak doświadczenia w zarządzaniu telepracownikami ${ }^{32}$.

$\mathrm{Z}$ punktu widzenia pracownika telepraca wiąże się $\mathrm{z}$ poczuciem izolacji społecznej $\mathrm{i}$ brakiem kontaktów międzyludzkich. Jak podaje Nilles, więcej osób byłoby zainteresowanych pracą w domu, gdyby nie ,kompleks biurowca"33. Mianem tym określił nieświadomą potrzebę przebywania w eleganckim miejscu pracy w celu zademonstrowania własnej wartości i prestiżu.

Telepraca może mieć negatywny wpływ na życie rodzinne, ponieważ może zacierać granicę pomiędzy pracą a życiem osobistym. Największa zaleta telepracy - praca w domu i opieka nad członkami rodziny - może się stać równocześnie największą wadą (mieszanie się sfery prywatnej, której odpowiada otoczenie domu, i sfery publicznej, czyli pracy zawodowej). Praca w domu i jednoczesne wypełnianie obowiązków domowych nie dają możliwości oddzielenia czasu pracy od czasu wolnego pracownika. W wielu przypadkach stały kontakt z domownikami może się wiązać ze spadkiem efektywności telepracownika. Wynika to stąd, że w tym samym czasie zajmuje się on pracą zawodową i sprawami, które nie są związane z pracą.

Dostrzegane są także inne wady tej formy pracy:

1) utrata umiejętności relaksu;

2) dystans od problemów zawodowych;

3) zagrożenie pracoholizmem;

4) uzależnienie od sprzętu technicznego.

Istotnymi barierami podjęcia telepracy oraz pracy w tym systemie są ponadto:

1) mniejsza możliwość awansu, gdyż będąc poza biurem, nie można się wykazać osiągnięciami;

2) dezorganizacja w pracy, ponieważ brak rutyny i zaleceń może prowadzić do złej organizacji pracy;

3) mniejszy dostęp do szkoleń;

\footnotetext{
${ }^{32}$ Por. M. Janiec, T. Czerniak, W. Kreft, R. Piontek, op. cit., s. 68-69.

${ }^{33}$ Por. J.M. Nilles, op. cit., s. 59.
} 
4) dłuższy dzień pracy, gdyż telepraca może prowadzić do wydłużenia dnia pracy bez wynagrodzenia;

5) obawa przed samozatrudnieniem - jest to sytuacja częsta w wypadku przechodzenia na system telepracy. Towarzyszą temu lękowi typowe objawy niepewności związane $\mathrm{z}$ byciem przedsiębiorcą ${ }^{34}$.

Zdarza się także, że brak osobistego kontaktu z przełożonym, a wyłączny kontakt przez urządzenia teleinformatyczne mogą prowadzić - w skrajnych przypadkach - także do psychicznego dyskomfortu u pracownika.

Wady i zalety telepracy w kontekście indywidualnym dla pracodawcy i pracownika nie są jedynymi, warto także zwrócić uwagę na korzyści i wady tego rozwiązania w kontekście społecznym. Z punktu widzenia społecznego podstawowymi korzyściami są:

1) Szansa za zatrudnienie osób niepełnosprawnych i związane z tym ograniczenie wydatków na świadczenia, np. renty;

2) redukcja bezrobocia związana $z$ tworzeniem miejsc pracy, $w$ tym także $w$ regionach słabszych ekonomicznie i z dużym bezrobociem, co pociaga za sobą ograniczenie wydatków na zasiłki dla osób bezrobotnych;

3) zwiększenie konkurencyjności przedsiębiorstwa zatrudniającego telepracowników;

4) poprawa środowiska naturalnego poprzez:

- eliminację ilości emitowanych spalin przez samochody osób codziennie dojeżdżających do pracy;

- zmniejszenie zużycia papieru, na które wpływa elektroniczny obieg informacji; czynnik ten wiąże się $\mathrm{z}$ aspektem ekologicznym, tzn. ograniczeniem wycinania lasów;

- dostrzeżono ponadto, że w wyniku telepracy oszczędza się także energię elektryczną;

5) poprawa bezpieczeństwa na drogach, gdyż mniejsza liczba samochodów wiąże się ze zmniejszeniem liczby wypadków komunikacyjnych;

6) integracja rynku pracy w skali światowej.

7) poprawa stosunków międzyludzkich;

8) poprawa wydajności przedsiębiorstw i pracowników;

9) ułatwienie małym i średnim przedsiębiorstwom rywalizacji z dużymi firmami;

10) stworzenie możliwości przyspieszenia restrukturyzacji zatrudnienia;

11) tworzenie bazy dla nowych usług i produktów;

12) poprawa jakości życia poprzez wprowadzenie nowych usług, np. bankowych, handlowych, medycznych ${ }^{35}$.

Oprócz zalet telepracy warto zwrócić uwagę na jej - wynikające ze społecznego punktu widzenia - wady. Wymienić tutaj należy przede wszystkim:

1) powstawanie coraz większych nierówności społecznych;

2) tworzenie się podziałów klasowych ze względu na dostęp do najnowszej technologii - na osoby mające do niej dostęp i te, które nie mają dostępu do tych technologii;

\footnotetext{
${ }^{34}$ Por. M. Janiec, T. Czerniak, W. Kreft, R. Piontek, op. cit., s. 67.

${ }^{35}$ Ibidem, s. 65; E. Bąk, op. cit., s. 64-65; A. Szewczyk, Telepraca i e-pieniqdze, [w:] Dylematy cywilizacji informatycznej, red. A. Szewczyk, PWE, Warszawa 2004, s. 148., s. 139.
} 
3) zróżnicowanie regionów pod względem rozwoju infrastruktury telekomunikacyjnej ${ }^{36}$.

Wśród wad telepracy na gruncie społecznym wskazywany jest także argument związków zawodowych, które obawiają się zaniku solidarności zawodowej w wypadku telepracowników $^{37}$. Można jednak przypuszczać, że ten niepokój wynika także z troski o osłabienie pozycji samych związków zawodowych w przedsiębiorstwie.

\section{PODSUMOWANIE}

Aktywizacja rynków pracy z wykorzystaniem telepracy może się odbywać na dwa sposoby. $Z$ jednej strony daje ona szansę lokalnym firmom, by uchronić się przed ograniczaniem produkcji lub wręcz umożliwić im rozwój. $Z$ drugiej strony pozwala konkretnym osobom znaleźć zatrudnienie poza miejscem zamieszkania bez konieczności migrowania. W pierwszym wypadku telepraca pozwala pozyskać lokalnej firmie rynki zbytu na swoje produkty poza miejscowym rynkiem albo sięgnąc po zasoby pracy niedostępne na danym obszarze. Firma mimo lokalnego charakteru ma szansę działać w szerszym wymiarze. Powiększenie rynków zbytu powinno pozwolić przyjać nowych pracowników już z lokalnego rynku pracy, niekoniecznie w zawodach związanych $\mathrm{z}$ technologiami opartymi na elektronice. W drugim wypadku ludzie szukający pracy na lokalnym rynku mogą ją znaleźć w firmach funkcjonujących poza danym regionem. Nadwyżka podaży pracy na miejscowym rynku może być wchłonięta, nawet gdy nie ma tu nowych inwestycji. Jawi się również jako szansa sięgnięcia do zasobów pracy z innego terenu. Natomiast osoby mieszkające na obszarach, gdzie występuje większy popyt na pracę niż jej podaż, mają szansę pracować bez zmiany miejsca zamieszkania. Pozwala to telepracownikom mieć stały kontakt z dziećmi i współmałżonkiem, jednocześnie daje szansę na zapewnienie bezpieczeństwa finansowego ich rodzinom.

Szczególnie kobietom znacznie trudniej jest zaleźć prace, zwłaszcza powracającym na rynek pracy po dłuższej przerwie oraz poszukującym pierwszej pracy. Okazuje się, że posiadane wykształcenie nie chroni kobiet przed bezrobociem. Bezrobotne kobiety są częściej lepiej wykształcone niż bezrobotni mężczyźni. Telepraca wydaje się jedną z form pracy dla osób, które zajmuja się np. wychowaniem dzieci czy kobiet w ciąży. Telepraca może się stać najczęstszą formą zatrudnienia kobiet nie tylko w okresie opieki nad małymi dziećmi, ale i na stałe. Argumentem może być uświęcenie jej jako idealnej formy pracy ze względu na możliwość godzenia obowiązków kobiety względem domu i rodziny. Z badań relacjonowanych przez Ewę Stroińską wynika bowiem, że głównym motywem podjęcia pracy w domu przez kobietę jest chęć połączenia ról rodzinnych i pracowniczych, z kolei w wypadku mężczyzn ten powód nie stanowi priorytetu $\mathrm{w}$ wyborze pracy $\mathrm{w}$ domu. Telepraca nie spełnia oczekiwań związanych z łagodzeniem napięć łączenia przestrzeni rodzinnej - prywatnej i publicznej - zawodowej. Może zatem się ona stać ideologicznie usprawiedliwioną „pułapką dla kobiet" ${ }^{\prime 38}$.

\footnotetext{
${ }^{36}$ E. Krok, op. cit.

${ }^{37}$ Por. K. Frankowski, Telepraca, czyli kto najbardziej boi się tego nowego zjawiska, w: Telepraca - szansq czy zagrożeniem na rynku pracy, Szczecin 2002, http//www.univ.szczecin.pl/zsgi/konferencja/5/ (dostęp: 15.05.2006)

${ }^{38}$ Por. E. Stroińska, Telepraca - szansq na aktywizacje zawodowq kobiet, ,Societas/Communitas” 2008/2, s. $299-311$.
} 
W pewnym zakresie może stwarzać możliwość podjęcia pracy również przez osoby niepełnosprawne czy będące w okresie rekonwalescencji, którym bariery architektoniczne, koszty i trudności związane z dojazdami do pracy uniemożliwiają podjęcie jej w tradycyjnej formie, nawet gdy osoby te mają odpowiednie wykształcenia. Dla tych jednostek, dla których opuszczenie własnego mieszkania i korzystanie z publicznego transportu jest dużym utrudnieniem, praca zdalna jawi się jako optymalne rozwiązanie, pozwalające na podjęcie pracy zawodowej. Dodatkową zaletą jest możliwość elastycznego kształtowania czasu pracy, co jest niezmiernie ważne w wypadku osób niepełnosprawnych. Mogą one bez przeszkód uczestniczyć w zajęciach rehabilitacyjnych, zasadniczo odbywających się w godzinach tradycyjnej pracy. Telepraca jest bardzo dobrym rozwiązaniem zawodowym dla osób, których niepełnosprawność dotknęła w późniejszym okresie życia, posiadających już wykształcenie i mających pewne doświadczenie zawodowe. Jest korzystną ofertą np. dla osób ze stwardnieniem rozsianym, osób z silnymi alergiami czy zaburzeniami psychicznymi połączonymi z różnego rodzaju fobiami $^{39}$.

Jest to także dogodna forma zatrudnienia dla wysoko wykwalifikowanych specjalistów z niektórych dziedzin, ceniących swój czas, a także dla tych, którzy szukają dodatkowego zatrudnienia. Telepraca może być także szansą dla regionów słabiej rozwiniętych i ich mieszkańców, a dla pracodawców - możliwością poszukiwania pracowników w rejonach, gdzie koszty wynagrodzenia są niższe. Z kolei trzeba pamiętać o ochronie praw pracownika, przeciwdziałać nadużyciom i łamaniu przepisów Kodeksu pracy, zgłaszanym przez telepracowników.

Praca na odległość ma zarówno swoje słabe, jak i mocne strony. Telepracę definiują cztery podstawowe cechy: użycie technologii teleinformacyjnych, geografia pracy (elastyczne miejsce pracy), jej czas i zawody związane z informacją. Do prawidłowego rozwoju tej formy aktywizacji zawodowej konieczne jest zatem rozwijanie nowoczesnych technik informacyjnych. Niemniej jednak telepraca jawi się jako bardzo nowoczesna forma, która jest w stanie zaktywizować lokalne rynki pracy i społeczności, a zwłaszcza grupy zawodowe najbardziej narażone na bezrobocie i społeczną marginalizację.

\section{LITERATURA}

[1] Bąk E., Elastyczne formy zatrudnienia, C.H. Beck, Warszawa 2006.

[2] Deptuła R., Teleworking jako alternatywna forma pracy w przysztości, „Praca i Zabezpieczenie Społeczne" 1998/4.

[3] Frankowski K., Telepraca, czyli kto najbardziej boi się tego nowego zjawiska, [w:] Telepraca szansq czy zagrożeniem na rynku pracy, Szczecin 2002, http//www.univ.szczecin.pl/zsgi/konferencja/5/ (dostęp: 15.05.2006).

[4] Jaczewski J., Telepraca i jej idea, [w:] Telepraca - rynek pracy bez barier, red. C. Mrozińska, Krajowy Urząd Pracy, Warszawa 2001.

[5] Janiec M., Czerniak T., Kreft W., Piontek R., Prowadzenie dziatalności biznesowej z zastosowaniem telepracy - poradnik, PARP, Warszawa 2006.

[6] Konarska E., Polańska K., Telepraca jako nowa forma organizacji pracy i zatrudnienia, [w:] Telepraca - szansa czy zagrożenie na rynku pracy, 2002, http//www.univ.szczecin.pl/zsgi/konferencja/5/ (dostęp: 15.05.2006).

[7] Koral J., Szluz B., Telepraca - szansa czy niemożność?, „Przemiana” 2009/3.

\footnotetext{
${ }^{39}$ Więcej na ten temat zob. J. Koral, B. Szluz, Telepraca - szansa czy niemożność?, „Przemiana” 2009/3, s. 18-19.
} 
[8] Krok E., Telepraca - aspekty ekonomiczna i społeczna, [w:] Telepraca - szansa czy zagrożenie na rynku pracy, Szczecin 2002, http//www.univ.szczecin.pl/zsgi/konferencja/5/ (dostęp: 15.05.2006).

[9] Książek D., Telepraca, „Praca i Zabezpieczenie Społeczne” 2004/7.

[10] Nilles J.M., Telepraca, strategie kierowania wirtualnq załogq, Wydawnictwo NaukowoTechniczne, Warszawa 2003.

[11] Nojszewski D., Telepraca, „E-mentor. Dwumiesięcznik Szkoły Głównej Handlowej w Warszawie", 2004/3, http://www.e-mentor.edu.pl/artykul/index/numer/5/id/61 (dostęp: 17.06.2013).

[12] Pawłowska M., Perspektywy rozwoju telepracy w Polsce - raport z badań, „E-mentor. Dwumiesięcznik Szkoły Głównej Handlowej w Warszawie" 2009/3, http://www.ementor.edu.pl/artykul/index/numer/30/id/662 (dostęp: 10.12.2010).

[13] Piasecki M., Telepraca osób niepetnosprawnych $w$ spoteczeństwie informacyjnym, „Telekomunikacja i Techniki Informacyjne” 20012.

[14] Romańska K., Elastyczna forma zatrudnienia - telepraca, [bw.], Warszawa-Łódź 2009.

[15] Stroińska E., Telepraca - szansq na aktywizację zawodowa kobiet, „Societas/Communitas” 2008/2.

[16] Szewczyk A., Szewczyk A., Telepraca i e-pieniadze, [w:] Dylematy cywilizacji informatycz$n e j$, red. A. Szewczyk, PWE, Warszawa 2004.

[17] Szymczak R., Internetowe miejsce pracy, Teczka informacyjna: Wojewódzki Urząd Pracy w Warszawie, Centrum Informacji i Planowania Kariery Zawodowej, Warszawa 2006, http://www.wup.mazowsze.pl/ciz/teczki/telepraca.pdf (dostęp: 10.05.2010).

[18] Ustawa z 24 sierpnia 2007 r. o zmianie ustawy - Kodeks pracy oraz niektórych innych ustaw (DzU 2007, nr 181, poz. 1288).

[19] Wiśniewski J., Zatrudnienie pracowników w formie telepracy, TNOIK, Toruń 2007.

\section{TELEWORK - MODERN, FLEXIBLE FORM OF EMPLOYMENT AND LABOUR - OPPORTUNITY OR THREAT?}

In the era of globalization and an information society we have to deal with changes in our approach to the issue of work. More and more it is becoming a service which is based on the use of modern information technology. One atypical form of performing work is telework. Telecommuting refers more specifically to work undertaken at a location that reduces commuting time. Major advantages for the employer are access to an expanded labor supply, a means of hiring part-time staff for cyclical work, and increased employee productivity. The primary advantages of home telework for the employee are the flexibility it brings to work, increased personal productivity, cost and time savings for able-bodied employees, and a job opportunity for the home-bound. Home office workers can be classified into distinct groups. The typical employees currently home teleworking are: self-disciplined full-time clerical women seeking income at reduced personal expense managerial and professional mothers wanting to nurture young children without dropping completely behind in their careers; and male managers or professionals who value the part-time integration of work and family life more than they do competition for further advancement in their organizations. Data support a generalized model of home teleworkers as individuals who will move in and out of part- or full-time work in home offices for intermittent or longer periods of time, as personal situations change. The origin and formation of the telework definition, its classifications, and the pros and cons in both individual and social dimensions are shown in the article.

Keywords: sociology of social problems, work, telework, employment

DOI: 10.7862/rz.2013.mmr.59 
Tekst złożono w redakcji: maj 2013

Przyjęto do druku: grudzień 2013 